\title{
THE ROLE OF THE FINANCIAL SUPERVISION AUTHORITY AND THE SITUATION OF THE CLIENT ON THE FINANCIAL SERVICES MARKET WITH SPECIAL EMPHASIS ON THE BANKING SERVICES MARKET
}

\author{
EDYTA RUTKOWSKA - TOMASZEWSKA*
}

\section{INTRODUCTION}

A well-functioning financial services market should be stable and transparent, as well as ensure security and protect the interests of its participants. These goals and tasks are defined in a number of legal acts, and an important role in their realization has been entrusted to the Polish Financial Supervision Authority as the oversight body for the financial services market. The Polish Financial Supervision Authority (hereinafter referred to as the FSA) has been equipped with tools allowing it to counteract impermissible actions of financial services market participants, such as entities subject to oversight due to their provisioning of financial services.

The subject of this paper is an analysis of the legal position of a client on the financial services market in respect of the FSA's tasks, with an indication of the scope and potential for its influence in not only what is commonly understood as oversight, but in a wider sense: in the framework of the FSA's entire set of duties related to the protection of a client's (user of financial services) interests, with special focus on the consumer.

\section{PURPOSE, SCOPE AND TASKS OF FINANCIAL SERVICES MARKET OVERSIGHT}

Pursuant to art. 1(2) of the FSMOA, ${ }^{1}$ oversight of the financial services market encompasses: the oversight of banking institutions, pension

DOI: 10.2478/wrlae-2013-0012

* PhD in Law; Assistant Professor, Department of Financial Law, Faculty of Law, Administration and Economics, Wroclaw University;

1 Financial Services Market Oversight Act 2006 (Journal of Laws 2012, item 1149), hereinafter: FSMOA 
schemes, insurance activities, capital markets, institutions involved in electronic money, ratings agencies, payment institutions and payment services offices, complementary oversight and oversight of credit unions and the National Savings and Credit Union. ${ }^{2}$ Particular oversight roles are defined and performed pursuant to the provisions set forth in sectoral legislation regulating the activities of particular financial institutions subjected to FSA oversight; the FSMOA refers to such acts, which include the manner of and instruments applied in such oversight.

The Financial Services and Markets Oversight Act does not define the concept of a financial market, in spite of its key significance. It is indirectly defined via the definition of oversight of the financial services market contained in art. 1(2) FSMOA, via the objective of such oversight contained in art. 2 FSMOA, and the tasks of the FSA as specified in art. 4(1) FSMOA.

The objective of oversight of the financial services market is to ensure this market's proper functioning, its stability, security and transparency, trust in the financial services market, and also to ensure the protection of the interests of the market's participants ${ }^{3}$ by fulfilling the objectives set forth in acts regulating the oversight of particular segments of the financial services market. The provisions of art. 2 FSMOA contain a definition of the goals of integrated oversight of the financial services market - common to the entire market, with reference to realization of the oversight objectives set forth in sectoral legislation.

In defining the concept of the 'financial services market', it is necessary to account for the normative context in which the Financial Services and Markets Oversight Act applies this concept, especially art. 6(1) and (2) FSMOA which establishes the instruments for achieving the goals of oversight of the financial services market. As a simplification, it may be assumed that the subjective scope of the concept of financial services market consists of its participants. On the basis of art. 1(2) FSMOA it should be considered that participants in the financial services market are those entities subjected to particular types of oversight constituting oversight of the financial services market. Banking oversight encompasses banks (domestic), the branches and offices of foreign banks, and the branches and offices of credit institutions (art. 131(1) BA - all of which

\footnotetext{
${ }^{2}$ As of 27 October 2012, Cooperative Banking Institutions (Co-ops) are under the oversight of the FSA pursuant to art. 60 of the Cooperative Banking Institutions Act 2009 (Journal of Laws 2012, item 855), and thus on that day the scope of financial services market oversight was widened.

${ }^{3}$ For more on the banking services market, see: ID Czechowska, 'Bezpieczeństwo klienta w procesach integracji sektora bankowego Stabilność sektorem ubezpieczeń' in J Nowakowski and T Famulska (eds), Stabilność i bezpieczeństwo systemu bankowego uwarunkowania wewnętrzn (Difin Warszawa 2008) 129-139; S Flejterski, 'Zaufanie do instytucji bankowo-finansowych jako fundament stabilnego systemu finansowego' in Nowakowski, Famulska (n 3) 17-66.
} 
constitute the banking market, or put differently, they are participants in the banking market and, by the same token, in the financial services market.

The tasks of the FSA as set forth do not constitute a closed catalogue and, in a manner analogous to the establishment of the objectives of integrated oversight contained in art. 2 FSMOA, concern the entire financial services market. They include (art. 4 FSMOA): exercising oversight of the financial services market as defined in art. 1(2) FSMOA; undertaking activities ensuring the proper functioning of the financial services market; undertaking activities intended to develop the financial services market and its competitiveness; undertaking educational and informational activities regarding the scope of the financial services market; participation in the preparation of draft legal acts in respect of oversight of the financial services market; developing instruments for the amicable and conciliatory resolution of disputes between participants in the financial services market, especially disputes arising out of contractual relations between entities subjected to FSA oversight and those using the services of such entities; and the performance of other tasks set forth by statutes.

\section{PARTICULAR AUTHORITY OF THE FSA CHAIRMAN}

The Financial Services and Markets Oversight Act grants special powers to the Chairman of the FSA. ${ }^{4}$ Pursuant to art. 6 FSMOA, the Chairman of the FSA has the authority to participate in civil and criminal proceedings. These solutions are designed to ensure the broadest possible protection of the interests of people participating in financial services market transactions.

The FSA Chairman is entrusted with the powers granted to the public prosecutor in the Civil Procedure $\operatorname{Code}^{5}$ in civil matters resulting from relations related to participation in transactions on the financial services market or concerning entities pursuing activity on this market (art. 6(1) FSMOA).

However, pursuant to art. 6(2)(2) FSMOA, in proceedings concerning activities violating the interests of market participants undertaken by entities performing commercial activity on that market, the FSA Chairman may, at his request, be granted the status of an injured party in criminal proceedings.

The same powers are granted to the FSA Chairman in matters concerning criminal acts set forth in art. 6(2)(1) FSMOA, in sectory statutes for financial institutions, and in the criminal provisions they are generally set forth in separate sections of those statutes.

In order to establish whether there are bases for submitting a notification of suspicion that a criminal act has been committed in respect of

\footnotetext{
${ }^{4}$ It is curious why these competencies have been granted to the Chairman of the FSA, and not the FSA itself, when it is the FSA and not its Chairman that is the financial services market oversight body.

5 Code of Civil Proceedings 1964 (Journal of Laws 1964, no 43, item 296 with amendments), hereinafter CCP.
} 
acts directed against the interests of capital market participants related to the activity of entities subjected to oversight, or for initiating administrative proceedings concerning violations of legal rules in the scope of Authority oversight, the FSA Chairman may order the instigation of explanatory proceedings. As a rule, explanatory proceedings are not performed under the rules of the Code of Administrative Procedure.

\section{FSA ACTIVITIES SUPPORTING THE PROPER FUNCTIONING OF THE FINANCIAL SERVICES MARKET IN RESPECT OF THE PROTECTION OF CLIENTS' (CONSUMERS') INTERESTS}

In realizing the statutory aims of oversight consisting in ensuring the proper functioning of the financial services market and the protection of market participants' interests, the FSA has undertaken, undertakes and, as it would seem to be justified, should undertake activities designed to counteract practices violating the collective interests of consumers, as well as eliminating unfair marketing practices, ${ }^{6}$ including on the banking services market.

It is also worth taking note of initiatives undertaken by the FSA on the basis of art. 11(1) FSMOA in respect of marketing communications. Among these measures are resolutions passed by the FSA containing principles for financial services market advertisements, ${ }^{7}$ including those

\footnotetext{
${ }^{6}$ For more on unfair market practices, including within the financial services market, see: the Combating Unfair Market Practices Act 2007 (Journal of Laws 2007, no 171, item 1206); M Sendrowicz, 'Naruszenie prawa konkurencji a możliwość dochodzenia roszczeń przez konsumentów, Prawo konkurencji na co dzień', (2007) 6 Biuletyn UOKiK; M Namysłowska, 'Zwalczanie nieuczciwych praktyk handlowych na podstawie dyrektywy' 2005/29/WE (I) (2007) 2 Przegląd Prawa Handlowego 2007; J Maliszewska-Nienartowicz, 'Dyrektywa o nieuczciwych praktykach rynkowych - pierwszy etap wspólnotowego prawa o zwalczaniu nieuczciwej konkurencji?' (2007) 1 Przegląd Prawa Handlowego 2007; E Rutkowska and M Sieradzka, 'Nieuczciwe praktyki rynkowe stosowane przez banki wobec kredytobiorców-konsumentów’ (part I); (2008) 2 Prawo Bankowe; part II - (2008) 3 Prawo Bankowe 2008; T Borkowski, 'KNF ostrzega' Gazeta Bankowa (25 March 2008) 10; T Borkowski, 'KNF ostrzega banki: Wycofajcie nierzetelne reklamy' Gazeta Bankowa (26 March 2008); 'Pułapki tkwią w opłatach' Gazeta Prawna (11 December 2006); R Poździk, 'Praktyki banków naruszające interesy konsumentów na przykładzie kart kredytowych' (2008) 3 Europejski Przegląd Sądowy 13; M Gzyl, T Świderek, M Rzemek and E Więcław, 'Praktyki niemoralne, ale legalne' Rzeczpospolita (18 April 2006); P Pietkun, 'Klient w malinach' (Gazeta Bankowa 2008) 46-48.

7 Resolution of the FSA of 3 July 2007 concerning a communiqué of the Financial Supervisory Authority in respect of forms of marketing investment funds; resolution of the FSA of 22 June 2007 concerning presenting the Banking Services Authority's position regarding marketing communications related to banking products; resolution of the FSA of 2 October 2008 concerning the rules for marketing of banking and insurance services; available at www.knf.gov.pl
} 
from banks. ${ }^{8}$ These resolutions constitute a continuation of activities designed to increase the level of security afforded to financial services market participants by ensuring them access to accurate marketing information.

Advertising is an important and constant element of communication between financial institutions and their clients, both current and prospective. The oversight body's tasks include ensuring that marketing materials produced by entities subjected to oversight have a fair and balanced influence on the decisions taken by their recipients. With regard to the requirements concerning marketing communications, the aforementioned acts state that they should be characterized by concern for clients' interests, honesty and conformance to generally applicable legal norms and good practices; they should not mislead nor create the potential for such, make reference to untrue or undocumented data nor be presented without essential information which may create the impression that the condition of an investment fund, investment risk or probability of profitable returns for investors is greater than if they were assessed on the basis of full information.

The content of marketing communications should be formulated in a manner appropriate to the knowledge and perceptive capabilities of an average recipient, taking into account the characteristics of the message's target group. In highlighting particular benefits of a financial product, it is impermissible to omit information that, if disclosed, may exert significant influence on the decision of the recipient.

It is also necessary in advertisements to present a scope of information that, when subjected to analysis by non-professional market participants, would allow for informed and conscious decision-making. In the opinion of the FSA, an advertisement should not constitute the sole basis for a decision, but rather an indication of other sources with which recipients should familiarize themselves prior to making their decision.

The FSA complements its activities in this scope by monitoring marketing messages, the purpose of which is to eliminate messages that could mislead the average user of financial services; such interventions are not at all rare in the case of banks. Such monitoring consists in reviewing informational and promotional materials published by, at the behest of or on behalf of entities overseen by the FSA. It has encompassed advertising materials emitted in selected press and television media, as well as printed flyers and marketing materials. There have also been periodic reviews of the websites of overseen entities, as well as of popular internet portals where marketing messages are disseminated. Additionally, information has been gathered concerning improprieties in marketing materials submitted by recipients of financial services, including by such means as a complaint form submitted via the FSA's website, which allowed for submissions of advertising messages that raised particular concerns.

Practices of banks and other financial institutions constituting dishonest or misleading advertising distort the functioning of the financial

\footnotetext{
${ }^{8}$ Resolution of the FSA of 2 October 2008 concerning the rules for marketing of banking services, available at www.knf.gov.pl
} 
services market to such an extent that the Financial Supervision Authority has also taken action directed at individual banks to eliminate unfair and misleading advertisements of banking products. ${ }^{9}$ The FSA has sent warnings to several banks (Millennium, BZWBK, Getin Bank) whose advertisements were acknowledged as dishonest, with an order to cease submitting dishonest, unclear, ambiguous, misleading and untrue information, and with an indication of further oversight measures to be taken. ${ }^{10}$

Of particular importance are undertakings by the FSA concerning informational obligations that can influence banks to conform to best practices by meeting such obligations, as the FSA signalizes particular improper activities of banks in this area by publishing communiques on its web page. The FSA can also inform the relevant institutions and authorities authorized to undertake appropriate measures and initiate relevant procedures. Additionally, there is a record of disciplinary measures taken by the FSA against entities on the financial services market that have acted to the detriment of consumers, especially against banks and other institutions subjected to FSA oversight. ${ }^{11}$

It is also necessary to highlight the particularly important educational activities undertaken by the FSA, ${ }^{12}$ by which information about the financial services market and services provided on it is disseminated. One of the statutory tasks of the Financial Supervision Authority is to undertake educational measures regarding the functioning of the financial services market by conducting a range of activities designed to expand and popularise knowledge about such subjects.

The FSA, with a view to improving the quality of marketing messages concerning services on the financial services market, has also conducted activities of an educational nature in the form of meetings, workshops and presentations for participants in the financial services market, during which the FSA presents its expectations regarding the manner of advertising services offered by entities on the financial services market. During these educational meetings the important role of marketing information in the process of communication with potential clients is highlighted, as well as the informational obligations placed on entities subjected to oversight. ${ }^{13}$

In addition, the scope of these activities includes undertakings in educational institutions, the informational website manymany.info, and

\footnotetext{
${ }^{9}$ See Financial Supervision Authority, Operations Report 2008 and 2009.

${ }^{10}$ Borkowski (n 6) 10.

${ }^{11}$ E Rutkowska-Tomaszewska, Naruszenie obowiązków informacyjnych banków w prawie umów konsumenckich, (Wolters Kluwer Polska, Warszawa 2009) 117.

12 For more on their characteristics, see: T. Nieborak, 'Europejski zintegrowany nadzór finansowy - aspekty instytucjonalno-prawne' in E Fojcik-Mastalska, E RutkowskaTomaszewska (eds), Bezpieczeństwo rynku finansowego (Prace Naukowe WPAiE Uniwersytetu Wrocławskiego, E-Monografie, no 6, Wrocław 2010) 51-65

${ }^{13}$ Financial Supervision Authority, Operations Report 2009
} 
publishing activities. ${ }^{14}$ The website of the Financial Supervision Authority (www.knf.gov.pl) itself plays an educational role, as it contains a range of materials useful in primary and secondary educational institutions; it also offers a service for the consumer of financial services.

The Financial Supervision Authority, in order to serve the interests of non-professional market participants and to shape proper bank practices, also undertakes activities to enhance the proper application of statutory regulations by financial institutions under its oversight, including by banks. These consist in the adoption of official positions directed at banks, additionally published on the FSA's website.

Owing to the constant growth in the number of complaints directed to the FSA against the financial institutions it oversees, the FSA released a resolution on 10 May 2011 intended to standardize the process and rules for submitting and reviewing complaints across all financial institutions overseen by the Authority. ${ }^{15}$ The resolution emphasises that a financial institution should ensure its clients the possibility of submitting a complaint in a manner that does not contain unnecessary barriers, and that the process of reviewing complaints by a financial institution should take place without undue delay, while being characterized by honesty, thoroughness, objectivity and respect for requirements of statutes in force and best practices.

A financial institution should exercise due care and observe the relevant statutes in force to register and retain a submitted complaint in such a manner that makes it possible to reproduce (in order to read or listen to) its contents and the contents of the response issued to the complaint. In the case of complaints submitted orally and acted on immediately by a financial institution, the obligation to record is incurred only upon the client's request.

The Authority has also undertaken activities designed to enhance the ethical robustness of financial institutions under its oversight by

\footnotetext{
${ }^{14}$ Financial Supervisory Authority, Guidebook for Financial Services Clients, Warsaw, May 2010; Financial Supervisory Authority, Electronic Banking Services for Retail Clients. Characteristics and threats, Warsaw 2010, available at www.knf.gov.pl.

In 2009, the Authority issued 6 educational brochures on the capital markets: 5 brochures authored by Prof. Krzysztof Jajuga from the series 'Institutions and rules of the capital markets. The anatomy of success', 'An Introduction to Financial Investments. Deposits and Money-Market Instruments', 'Bonds and Shares', 'Derivative Instruments', 'Basic Investment Strategies' and 'Secondary Market for Securities', 'The Investor's Guidebook'; and 'First Steps on the Capital Market' by Piotr Szulec and Piotr Biernacki. These brochures are forwarded to libraries, secondary schools and institutions of higher learning, and financial market institutions.

15 The complaint deadline means every communication from a client to a financial institution concerning his/her complaints relating to services offered by that institution or its activities.
} 
commencing work ${ }^{16}$ on the Canon of Financial Services Market Best Practices ${ }^{17}$.

The Canon of Financial Services Market Best Practices articulates the fundamental ethical values and principles guiding financial institutions, and the rules in the Canon constitute an integral, complementary whole. At the same time, the Canon grants financial institutions and their selfgovernance institutions the freedom to shape and evaluate the applications of ethical standards in accordance with the specific nature of individual market sectors and various organizational solutions, and also with their achievements in the creation and improvement of best practices rules.

Codes of best practices constitute a sort of set of behavioural norms based on self-regulation and self-oversight by enterprises. Their individual nature results from the fact that they constitute a counterbalance to mechanisms based on legal regulations that restrict the freedom of action for enterprises on the market. It may thus be stated that these restrictions are introduced voluntarily by the enterprises concerned, who are the signatories to the rules for activity contained in codes of best practices. It should not, however, be forgotten that in a situation in which such restrictions do not result from legal norms enforced by legal mechanisms of repression, but rather from self-discipline, it should be a self-discipline organized in a sufficiently broad and effective manner.

The Canon of Financial Services Market Best Practices emphasises standards and rules which are important for the functioning of the financial services market: honesty, diligence and competence, preventing conflicts of interest, proper provision of information about products and services offered, avoiding misleading clients as to the risk associated with potential benefits, and the amicable resolution of disputes.

The Financial Supervision Authority has undertaken cooperation with various institutions with a view to eliminating the improper behaviours of overseen entities. These include: the Central Anti-Corruption Bureau - in respect of uncovering, fighting and preventing criminal activity and threats present on the financial services market ${ }^{18}$; the Office of Competition and Consumer Protection ${ }^{19}$ and the Consumer Federation ${ }^{20}$ - to ensure the protection of participants on the financial market and to counteract practices

\footnotetext{
16 Financial Supervision Authority, Resolution no 752/07 (22 June 2007) concerning support for the adoption of the Canon of Financial Services Market Best Practices, and Financial Supervision Authority, Resolution no 99/08, (18 March 2008) concerning recommendations for applying the Canon of Financial Services Market Best Practices, available at www.knf.gov.pl.

${ }^{17}$ See minutes from the FSA session of 9 May 2007, available at www.knf.gov.pl.

${ }^{18}$ Understanding of the FSA represented by its Chairman and the head of the Central Anticorruption Bureau of 28 May 2008 (CBA Journal of Laws 2008, no 2, item 26).

19 See FSA communiqué of 27 July 2007 concerning the signing of a memorandum of cooperation with the Office of Competition and Consumer Protection at www.knf.gov.pl.

20 Communiqué of CF and FSA of 7 February 2008 concerning the signing of a memorandum of cooperation at www.knf.gov.pl
} 
which violate the collective interests of consumers, and also to eliminate unfair practices, including in the area of marketing.

The fact that the FSA has undertaken cooperation with the Consumer Federation (a consumer organization ${ }^{21}$ ) and the President of the OCCP demonstrates the necessity of undertaking comprehensive activities involving the cooperation of various entities, including with the authority responsible for oversight of the financial services market, to eliminate unfair practices, and simultaneously proves the high level of threats to consumer participants in the financial services market due to the specific nature of this market and the services offered on it.

\section{ENABLING AMICABLE DISPUTE RESOLUTION ON THE FINANCIAL SERVICES MARKET - THE FINANCIAL SUPERVISION AUTHORITY COURT OF ARBITRATION}

One of the FSA's tasks is to enable the amicable and conciliatory resolution of disputes between financial services market participants, including disputes resulting from contractual relations between entities subjected to the Authority's oversight and recipients of services provided by such entities (art. 4(1) FSMOA). An expression of this was the founding of the Financial Supervision Authority Court of Arbitration, foreseen in art. 4 and 18 FSMOA. ${ }^{22}$

The FSA Court of Arbitration, from its inception, became an additional mechanism alongside the Bank-Consumer Arbitration Panel for the amicable and conciliatory resolution of disputes, especially those arising from contractual relationships between banks professionally providing financial services subject to FSA oversight and their non-professional counterparties, the consumers.

The Court takes part in the resolution of disputes between financial institutions and between those institutions and recipients of financial services, subject to their mutual consent to submitting a matter to the Court of Arbitration. The Court resolves disputes between participants of the financial services market, primarily between insurance firms, mutual funds, pension investment schemes, brokerage houses, banks and the recipients of services offered by such institutions, including consumers.

The primary condition for bringing a dispute before the Court is gaining consent from the defendant by the complainant. If the complainant is a consumer, he may file a request with the Court to seek the consent of the defendant to hear the matter before the Court of Arbitration. The Court resolves disputes concerning property rights whose value is equivalent to at least PLN 500, as well as non-property rights. The Court can hear cases in

\footnotetext{
${ }^{21}$ For more on the role of consumer organizations in protecting the interests of consumers, see: E. Rutkowska, 'Rola organizacji konsumenckich w ochronie konsumentów na przykładzie rynku usług bankowych' in J Blicharz and J Boć (eds), Prawna działalność instytucji społeczeństwa obywatelskiego (Kolonia Limited, Wrocław 2009).

22 The FSA Court of Arbitration began functioning on 31 March 2008.
} 
which the value of the dispute is less than PLN 500 if the consumer provides justification of the exceptional nature of the dispute indicating the necessity of it being reviewed by the Court of Arbitration.

The scope of matters that the FSA Court of Arbitration reviews is wider than that of the Banking Arbitration Panel. The subject of the dispute can be not only pecuniary claims arising from the non-performance or improper performance of banking activities by a bank on behalf of a consumer, but all property and non-property rights that may constitute the subject of an agreement. The competitive character of proceedings before the FSA Court of Arbitration is thus limited to those disputes that are also within the jurisdiction of the Banking Arbitration Panel. The Regulations of the FSA Court of Arbitration do not foresee an upper limit to the monetary value of the subject of a dispute, whereas the Bank-Consumer Arbitration Panel has no jurisdiction over matters in which this value, excepting interest and other claims outside the primary claim, exceeds PLN 8,000. Proceedings before the FSA Court of Arbitration are also more costly there is a fixed fee of PLN 250, whereas the cost borne by a consumer making use of the Bank-Consumer Arbitration Panel amounts to either PLN 50 or 20 , in the event the value of the subject of the dispute is below PLN 50. Verdicts issued and settlements concluded before the FSA Court of Arbitration, upon validation by a common court appropriate to the place and subject of the dispute as indicated by the Code of Civil Proceedings, have equal force of law to a common court verdict. A consumer dissatisfied with a ruling issued by the Banking Arbitration has the possibility of further pursuing his claims and can file suit in a common court.

Prior to commencing amicable dispute resolution proceedings, the parties have the possibility of entering into mediation in order to resolve their conflict.

The justices inform consumers who are not represented by professional attorneys of their rights resulting from the proceedings initiated.

One result of the founding of the FSA Court of Arbitration is an increase in competitiveness among the alternative dispute resolution methods available to consumers, which should have a salutary effect on the level of protection afforded to them. ${ }^{23}$ This may, however, seem illusory when examining the scope of matters reviewed and the procedural solutions foreseen in the Regulations of the FSA Court of Arbitration.

23 E Więcław, 'Rusza sąd dla klientów' Rzeczpospolita (24-25 November 2007) B1; S Kluza, 'Powstanie sąd polubowny przy Komisji Nadzoru Finansowego' Rzeczpospolita (9 October 2007) C8; E Rutkowska, 'Sąd Polubowny przy Komisji Nadzoru Finansowego nowym rozwiązaniem $\mathrm{w}$ zakresie alternatywnych sposobów rozwiązywania sporów miedzy uczestnikami rynku finansowego' (2008) 4 ADR 77-89; E Rutkowska and D Wojtczak, 'Alternatywne sposoby rozwiązywania sporów miedzy bankiem a konsumentem usług bankowych' (2008) 7/8 Prawo Bankowe 72-88; A Zaręba, 'Sąd Polubowny przy Komisji Nadzoru Finansowego' (2009) 1 Radca Prawny 2009. 
Professional entities that may participate in disputes before the Banking Arbitration include all banks with membership in the Polish Bank Association, as well as those which are not its members, but have submitted themselves to the decisions of the Banking Arbitration and consented to enforce its rulings. Proceedings before the FSA Court of Arbitration are only possible when a consumer's professional counterparty has consented to them either via a contractual arbitration clause, or at a later time by expressing consent in respect of a particular case. Future bank practice will determine the competitive effectiveness of proceedings before the FSA Court of Arbitration with regard to the Bank-Consumer Arbitration Panel.

The broadly-understood function of protection of the interests of non-professional participants in the financial services market (including bank clients) includes the handling of complaints and other individual interventions concerning improprieties of various seriousness in the functioning of entities under oversight. This is an indirect means of settling disputes, and not of resolving them. Information taken from complaints about disputes between overseen entities and their clients makes it possible to obtain important data on phenomena emerging on the market. The object of analysis is the behaviour of overseen entities in matters presented by complainants. The scope of activities undertaken may include steps intended to establish the facts and legal character of a matter at hand with a view to potentially applying oversight measures, as well as informing an interested party of procedures foreseen by statute for pursuing claims in the event of a dispute possessing civil-law characteristics. After analysing complaints resulting from declared improprieties, the FSA has applied a range of oversight measures in order to eliminate practices found to violate the interests of non-professional participants in the financial services market.

The FSA website (www.knf.gov.pl) contains complaint forms tailored to the categories of entities under its oversight. They contain detailed explanations making them easy to fill in, and may be sent electronically. This is an exceptionally important FSA undertaking which helps build the awareness of consumers and other non-professional participants in the financial services market. For a complaint to be successfully lodged, and, as a result, for an answer to the complainant to be issued, all the obligatory fields in the form must be filled in; this includes fields for a detailed description of the factual situation and concrete indications of the improprieties on which the complaint is based.

The Financial Supervision Authority has also taken steps to introduce Consumer Arbitration, in accordance with the recommendations of the Supreme Audit Chamber indicating the necessity of improving the effectiveness of alternative dispute resolution methods on the financial services market. The FSA proposal assumes that Arbitration will encompass disputes involving financial services market consumers limited to relatively small claims (approx. PLN 10,000), and the participation of financial institutions in Arbitration will be obligatory. A draft bill has been presented 
to the OCCP and the Chancellery of the Prime Minister, ${ }^{24}$ and has also been presented during a session of FINNET. ${ }^{25}$

It would seem that the introduction of Consumer Arbitration may strengthen the protection of consumers on the financial services market and improve their position in disputes with financial institutions, as well as serve to secure their rights. The need for such an institution is indicated by the large number of complaints received by the Financial Supervision Authority every year.

\section{APPLICATION OF OVERSIGHT MEASURES TO PROTECT CLIENTS' INTERESTS}

Performing its role in bank oversight, the Financial Supervision Authority possesses statutorily-defined measures for taking action against entities it oversees. These oversight measures are primarily intended to prevent the occurrence of situations in a bank that would threaten the security of its clients. For this reason, pride of place in the catalogue of oversight measures belongs to the recommendations that the Authority can address to a bank under its authority. Oversight measures can be applied against a bank in order to align a factual situation with the requirements of the law, as well as to prevent activities contrary to it.

Bank oversight measures are instruments that permit the FSA to take measures directly interfering in the activity of existing banks under its authority - these are individual means of oversight directed at a specified bank.

The Banking Act foresees a catalogue of potential oversight measures applicable by the FSA. They are binding on those to whom they are addressed. From the point of view of the entity/addressee of an oversight measure, they can be divided into two groups: those affecting the banking institution itself (the overseen entity) - so-called general oversight measures (ad rem), and those affecting individuals performing functions in the bank's internal structures (the management board) - so-called special measures ( $\mathrm{ad}$ personam).

The first group encompasses recommendations, ${ }^{26}$ including desisting in particular forms of advertising, orders to suspend dividend payments and to create new internal organizational structures at the bank (forbidding the

\footnotetext{
24 Letter from the FSA of 18.08.2011 concerning bank-consumer arbitration to the Chancellery of the Prime Minister and the President of the Office of Competition and Consumer Protection, and also to the Insurance Ombudsman, made available to the author by the FSA.

25 See Financial Supervision Authority, Operations Report 2011, available at www.knf.gov.pl

${ }^{26}$ Amongst ad rem measures the FSA can require a bank to undertake particular steps (eg increase its own funds or cease a certain type of marketing).
} 
bank's organizational expansion), limiting the scope of the bank's activity (e.g. to only some banking activities), revoking the licence to found a bank (primary licence) and taking the decision to liquidate a bank.

The second category includes submitting a request to remove a bank's board members from their posts, suspending members of the board until the relevant resolution is undertaken by the supervisory board at the nearest session, removing a bank's board members, and assessing monetary penalties on the members of a bank's board.

Some measures are of a preventative nature, and are intended to guard against the arising of an undesirable situation in a bank's activities or to lead to a beneficial factual situation (e.g. the restoration of liquidity or conformance to capital requirements). Others, however, are repressive they are the reaction of the FSA to an undesirable situation.

The catalogue of potential measures is essentially closed. This does not apply, however, to individual recommendations, which can be applied in every case insofar as they are undertaken in the framework of oversight (art. 138(7) and art. 133(2) of the Banking Act), and thus may be formulated as an element of the subjective scope of bank oversight.

Legal measures undertaken within the framework of banking oversight can relate only to entities subjected to oversight; they may not influence the legal situation of a bank's counterparties, nor may they alter the terms of a contract concluded by the bank save for those concluded by domestic banks with entities in the same holding group and those concluded between a domestic bank and entities with which it is closely linked (art. 138(7) Banking Act).

Application of a measure does not form the basis for altering or dissolving a contract already concluded. However, some measures may indirectly influence the legal situation of a bank's counterparty. The FSA has been granted the power to issue a decision forcing a bank to undertake actions leading to changes in or dissolution of a contract serving as the basis for entrusting it with the performance of tasks set forth in art. $6 a(1)$ of the Banking Act $^{27}$ under an outsourcing regime (art. 6c(4-6) Banking Act). This instrument is of special significance as it is an exception to the rule which states that administrative oversight measures applied by the FSA may not, with limited exceptions, interfere in the contents of contracts concluded by banks (art. 138(7) Banking Act).

In examining the possibility of applying oversight measures against banks in the event they are determined to operate in violation of their clients' interests, it would appear that recommendations may be issued concerning the cessation of certain forms of marketing, especially dishonest and misleading ones (such a determination may be made on the basis of the aforementioned principles for advertisements of banking products).

\footnotetext{
27 The FSA has also received additional competencies concerning oversight of activities entrusted by banks to domestic and foreign enterprises, defined in art. $6 \mathrm{a}(1)$ Banking Law, in an outsourcing regime. The statute considers a domestic or foreign enterprise that a bank has entrusted tasks to as an entity with close ties to the bank, and thus making it subject to regulations concerning consolidated oversight.
} 
It is, however, worth drawing attention to art. 141 of the Banking Act, amended on 25 October 2011 by the Payment Services $\mathrm{Act}^{28}$, which regulates measures applied against a branch of a credit institution operating in Poland. Pursuant to art. $141 \mathrm{a}(2 \mathrm{a})$ of the Banking Act, if a credit institution conducting commercial activity via a branch in Poland fails to observe the provisions of Sections II and III of the Payment Services Act concerning informational obligations in respect of the provision of payment services and the rights and responsibilities of suppliers and users of payment services, the Financial Supervisory Authority then acquires additional competencies. It summons the credit institution in writing to adhere to the aforementioned regulations, and sets out a deadline for fixing any declared improprieties. Following the passing of this deadline without action on the part of the payment institution, the FSA may apply the following measures constituting only a portion of those applied against domestic banks encompassed by what is referred to as full FSA oversight. Specifically it may:

- submit to the appropriate internal bank authority a motion to dismiss the president, vice-president or any other member of the bank's management board directly responsible for the declared improprieties,

- limit the scope of the bank's or its organizational units' activities,

- levy a penalty against the bank of up to $10 \%$ of the revenues reported in the last verified financial statement, and if there is no such statement - a penalty of up to $10 \%$ of forecast revenues as determined on the basis of the bank's financial situation, not to exceed the sum of PLN $10,000,000$.

The Financial Supervisory Authority also informs the appropriate supervisory authority in the institution's home country about the declared improprieties and measures taken. In urgent cases, the Financial Supervisory Authority may take action without prior written notice as necessary to protect the interests of depositors.

Indirect oversight instruments serving to protect the interests of bank clients can be considered to result from the FSA's authority in the area of outsourcing. The Financial Supervisory Authority has the power to issue a decision forcing entities to undertake actions aimed at altering or dissolving an outsourcing contract ${ }^{29}$ in cases where its performance may involve risk to the careful and stable management of the bank, or when the outsourcing partner (a domestic enterprise or foreign enterprise that is party to the

\footnotetext{
28 Payment Services Act 2011 (Journal of Laws 2011, no 199, item 1175 with amendments).

29 This contract has been regulated in art. 6a(1) Banking Act, and its material concerns entrusting a domestic or foreign enterprise with the performance of intermediary services on behalf of and to the benefit of the bank on the basis of an agency contract, consisting of: concluding and amending credit contracts for financing residential investments, accepting orders for conducting bank settlements related to the servicing of accounts by that bank, and also the performance of other activities upon receiving permission from the FSA.
} 
contract) loses the capacity to perform its obligations under the contract. Additionally, the FSA has the right to apply the measures set forth in art. 138(3) of the Banking Act without a prior written reprimand in the event the bank fails to alter or dissolve the outsourcing contract. Thus, the FSA has the authority to issue a decision ordering a bank to undertake to amend or dissolve a contract serving as the basis for entrusting the performance of activities set forth in art. $6 \mathrm{a}(1)$ of the Banking $\mathrm{Act}^{30}$ under an outsourcing regime (art. 6c(4-6) Banking Act).

The bank may submit an appeal against a decision of the FSA to an administrative court within 14 days of obtaining the decision, and there is no right to submit a request to re-hear the matter.

\section{CONCLUSiOns}

Of fundamental importance to the development of the financial services market is a feeling of security among its participants, which is influenced in some measure by state oversight. Transactions must be felt to be honest and credible in the eyes of clients. Oversight as exercised by the FSA has a significant influence on eliminating risk factors that are not the results of the normal rules of the financial services market's operation. Within the scope of its oversight, the Financial Supervision Authority examines whether the interests of market participants and their security have been violated. It is also equipped with the capacity to undertake actions of a direct nature - operating on the basis of competences granted to it by particular regulations concerning its tasks, or also indirectly - in situations when it doesn't have the standing to instigate the appropriate procedures, if it possesses information about violations and improprieties it can forward such information to authorized bodies in order to set in motion the relevant mechanisms. The problem lies only in their activity in this area, and also in shaping certain best practices of cooperation between institutions and the public authorities responsible for defending the rights of financial services customers, especially of consumers.

To ensure real protection for consumers, the active participation of the appropriate institutions, authorized to initiate proceedings, is of paramount importance. This primarily concerns the President of the OCCP, the consumer ombudsmen, consumer organizations, and lastly the FSA. The Authority takes action based on the Financial Services Market Oversight Act; this action is direct when the capacity to do so results from the statute, and indirect when, not in possession of standing, it still possesses information on violations and improprieties coming directly from the financial services market itself.

\footnotetext{
30 The FSA has also received additional competencies concerning oversight of activities entrusted by banks to domestic and foreign enterprises, defined in art. $6 \mathrm{a}(1)$ Banking Law, in an outsourcing regime. The statute considers a domestic or foreign enterprise that a bank has entrusted tasks to as an entity with close ties to the bank, and thus making it subject to regulations concerning consolidated oversight.
} 
The FSA's activities, while formal, often take on an unofficial character, meaning that the FSA has the capacity to address particular entities regarding their improper conduct, issuing recommendations for changes, and in this way it can also encourage the banks themselves to eliminate bad practices; it can also wait and see if its comments are taken note of, and then undertake further actions to notify the relevant bodies in possession of appropriate instruments or take direct action within the scope of oversight measures set forth in statute.

By performing its duties properly, the FSA can have a positive effect on the relationships between entities providing financial services and their clients, by restoring a semblance of balance and fairness. 